\title{
The Recontextualization of altruistic rhetoric in managerial discourse: The reductive and productive effects of a municipal management plan
}

\section{Diana Wegner}

Cet article rend compte d'une étude des effets de l'incorporation d'énoncés altruistes (Foncault, 1972) dans le développement en collaboration d'un plan compréliensif de développement des endroits naturels d'une municipalité. C'est une tentative de tracer l'appropriation et la recontextualisation des discours environnementalistes et communautaristes contemporains dans le discours de la gestion civile, et plus spécifiquement, dans le Plan de gestion des aires naturels développé par le Département des parcs municipaux. L'étude décrit les formations discursives qui sont facilitées par ces recontextualiszations (Bakhtin, 1981; Fairclough et Wodak, 1997; Iedema, 1999; Sarangi, 1998) et suggère que l'impact pratique que ces valeurs altruistes cherchaient à produire dans leurs discours antérieur est effectivement réduite à la fois dans le discours des gestionnaires à propos du plan lui-même et de l'ensemble du le projet relatif aux aires naturels.

Le plan semble promouvoir les intérêts des groupes de gestionnaires municipaux et d'une certaine élite dee la communauté; D'autre part, il tend à exclure une participation communautaire plus englobante et à éviter de faire face aux éléments conflictuels du projet. Des analyses textuelles des termesclefs utilisés à l'intérieur des discours visés prouvent que l'opposition au plan et le désintérêt par rapport à celui-ci sont anticipés par les gestionnaires, ce qui les mène à ignorer les aspects environnementalistes et de responsabilisation de la communauté commun et de se replier sur des concepts hybrides de " développement viable et durable » et de "communautés viables " (Burke, 1966). Cette stratégie greffe sur une terminologie écologiste une les conception du "développement» conçue en tant que croissance économique, impliquant de ce fait la présence d'une opposition au développement mais ne reconnaissant à excluant de telles voix aucune reconnaissance explicite. La même stratégie greffe également au mot "communauté", non pas des notions de 
dévolution de pouvoir, de responsabilisation ou de 'empowerment par la participation, mais bien une notion de "viabilité "qui elle-même évoque la notion de viabilité économique communautaire, référant sans jamais toutefois le nommer au fait problématique que la participation communautaire à ce processus public demeure inadéquate.

On y fait valoir le fait que les gestionnaires eux-mêmes par le biasi du discours qu'ils tiennent récupèrent l'effets altruistes produit par d'autres discours et se les approprient dans le but de servir leurs propres intérêts. Ceci semble est produit en partie par le déploiement de dispositifs stylistiques du discours-type des gestionnaires qui en limitent l'accessibilité (Killingsworth et Palmer, 1992), qui peuvent aussi être décrits iconiquement par les structures de gestion, en même temps que le produit, en partie, du pouvoir institutionnel qui pr »ecède le discours et appuie les intérêts de la gestion. (Fairclough, 1992; Foucault, 1972; Giddens, 1984; Lyotard, 1988; Mumby, 1988; Wodak, 1996).

This paper reports on a study of the effects of the incorporation of altruistic "statements" (Foucault, 1972) in the collaborative development of a comprehensive plan to manage the natural areas of a municipality. It is an attempt to trace the appropriation and recontextualization of the discourses of environmentalism and contemporary communitarianism into the discourse of civic management, and specifically into the Natural Areas Management Plan developed by the city's Parks Department. The study describes discursive formations that are enabled by these recontextualizations (Bakhtin, 1981; Fairclough and Wodak, 1997; Iedema, 1999; Sarangi, 1998) and suggests that the intended pragmatic force of these altruistic values in their antecedent discourses becomes reduced in both the managerial discourse of the plan and the natural areas project overall.

The plan seems to foster the interests of management and elite community groups; on the other hand, it tends to be exclusionary of wider community participation and to elide conflictual elements of the project. Textual analyses of key terms of the implicated discourses show that anticipated opposition and disinterest in the plan lead managers to deflect the implications of envi- 
ronmentalism and community empowerment, and to select instead hybrids like "sustainable development" and "sustainable communities" (Burke, 1966). This strategy grafts onto an environmentalist term the connotations of "development" as economic growth, implying the presence of pro-development opposition but excluding such voices from any explicit acknowledgment. The same strategy also grafts onto the term, "community," not notions of empowerment through participation, but instead connotations of "sustainability" that evoke economically viable communities, implying but not stating the felt problem of inadequate public participation in a public process.

It is argued that managerial discourse and managerial power co-opt the intended altruistic effects of other discourses that are appropriated to serve management interests. This seems to occur partly through the deployment of those stylistic features of managerial discourse that limit accessibility (Killingsworth \& Palmer, 1992), which may be described as iconic with management structures, and partly as an effect of the institutional power that buttresses management interests and precedes discourse (Wodak, 1996; Fairclough, 1992; Mumby, 1988; Lyotard, 1988; Giddens, 1984; Foucault, 1972).

Studies of written communication in organizational settings fall into the general areas of enculturation of new or marginal members (Beaufort, 2000; Lutz, 1989; MacKinnon, 1993), the dynamics of competing interests and genres (Beaufort, Herndl, Fennell and Miller, 1991; Sauer, 1994; Schryer 1994; Winsor, 1994) and the effects of institutional forms of discourse (medical, legal, and educational) in the context of asymmetrical power relations (Agar, 1985; Cicourel, 1982; Coulthard, 1977; Edelman, 1984; Stygall, 1991; West, 1984). More recently, out of this last area of research on discourse and organizational power, the phenomenon of "recontextualization" and "interdiscursivity" ("mixed discourses") has been explored in the context of discursive changes affecting dominant and non-dominant discourses (Fairclough and Wodak, 1997; Iedema, 1999; Mumby, 1988; Sarangi, 1998; Wodak, 1996). These latter studies have explored medical, bureaucratic, legal, and managerial discourses; they suggest how recontextualization and interdiscursivity may function as a strategy of power. Analyses have focused on both recontextualizations, from text to text, and interdiscursivity, the mixing of different discourses which is conceived as a phenomenon greater than but inclusive of the strictly textual (Fairclough, 1992). 
This paper belongs to this effort to analyze and explain the significance of orders of discourse. It is focused on the heterogeneous co-existence of four different discourses: environmentalist, communitarian, economic, and managerial. The study is based on research into an ongoing project, the development of a municipal management plan by a Parks and Recreation department for all the city's remaining publicly owned natural areas, which are considerable and the object of developers' interests. The findings reported here are framed by the following theoretical orientations: postmodern theories of power, specifically Foucault's concepts of the statement and discursive formations (1972), Bakhtin's concept of recontextualization (1981), recent developments of both intertextuality and interdiscursivity (Fairclough, 1992; Fairclough and Wodak, 1997; Iedema, 1999; Sarangi, 1998; Wodak, 1997), and Burkean rhetorical theory (1969 and 1966).

A social approach to analysis has been adopted in this study in an effort to produce a more comprehensive and accurate picture of the specific context and processes at work in the mixings of discourses. This approach includes an examination of both textual and contextual elements of the processes of recontextualization and interdiscursivity: textual analyses occur in the context of the interdiscursive relations of speaking subjects (participants in the natural areas project), developments in related professional fields, and city politics. Efforts to respect and include relevant contextual material include the use of documents that were identified by participants as influential in the development of the Natural Areas Management Plan (NAMP) and the compilation of commentary from participants elicited through interviews and questionnaires, and unelicited at meetings.

The findings of this study suggest that economically driven managerial discourse tends to appropriate and recontextualize statements from the altruistic discourses of environmentalism and communitarianism (a contemporary philosophy of citizen participation and empowerment derived from earlier politically motivated and emancipatory incarnations and adapted as cooperative and collectivist community organizations), with pragmatic effects that favour management interests. As the recurrent key terms of these altruistic discourses are imported out of global and into professional contexts, including the language of the NAMP, the recontextualizations produce discursive formations that advance managerial and particular citizen group interests, but limit potential dialogue, accessibility, and participation where perceived conflicts might occur. That is, the recontextualized terms may carry the altruistic meaning of their statements, but their strategic repetitions, inflected for example as "sustainable communities," become susceptible to managerial interests-even where management intentions appear to be altruistic themselves. A mixing of statements from these discourses seems to enable management structures, but is much less ena- 
bling of the altruistic goals of environmentalist or "community development" initiatives. "Community development" is a North American term for current communitarian models.) For example, "development," a key term in these mixtures, carries a strategic double-voicedness, signifying both protection, as in "environmental sustainability," and economic growth (a city priority), as in "sustainable development." Evidence supporting this analysis shows a textual and contextual ambivalence between altruistic and economic goals as they are articulated in the plan-an ambivalence that is also shown to exist between the readership it invokes and the avowed readership it excludes.

In the following, I first present the key analytical concepts that buttress the theoretical framework for this study. In this section, I describe the incorporated theories of discursive appropriation and the operation of recontextualization, interdiscursivity as the mixing of discourses, and the exclusionary features of managerial discourse. The research methodology for this study is then elaborated as an ethnographic, qualitative approach that includes analyses of a range of textual sources (antecedent and foundational documents, professional literature, municipal reports, and minutes) and other empirical methods (questionnaires, interviews, a focus group interview, and observations at meetings). Background to the natural areas management project is then provided (incorporating orally given data), followed by a section that presents and discusses the salient findings of the study. These findings focus first on textual analyses of a series of recontextualizations that become salient in the NAMP, and that have interdiscursive implications. Findings also include a discussion of the stylistic features of managerial discourse that contribute to an exclusionary effect, and the responses of participants in the project to this exclusion, in both the text of the written plan and in the larger situation. A concluding section returns to the relationship between discourse and power, and raises the question of the residual problem of the anteriority and primacy of power, and the role of discourse analysis in broaching this problem.

\section{Theoretical Background}

\section{Recontextualization, interdiscursivity, and exclusionary discourse}

Two concepts from the theoretical framework require some initial, if provisional, clarification: "discourse" and the "statement." They are used here in their essentially Foucaultian meanings (1972) but with important elucidations offered by Fairclough (1992). "Discourse" is used as a multidimensional concept that combines the "socialtheoretical sense of 'discourse' with the 'text-and-interaction' sense in linguistically oriented discourse analysis" (4). In other words, discourse can refer to both "discur- 
sive formations," that is, "different ways of structuring areas of knowledge and social practice," as in environmentalist, medical, or legal discourses, and it can refer to "extended samples of either spoken or written language" (3). In this study the sociotheoretical meaning is primary, although in places the second use of the term is unavoidable.

The second concept, "the statement," refers to a recognizable sociolinguistic phenomenon made up of "various units" (for example, "fragments of sentences" or "sets of propositions" or "tables of signs") that can be examined and conveyed through language, but that cannot be reduced to language (Foucault, 1972, p. 106). What makes certain statements possible at a given time is the system of rules that operationalize a discourse. In one of Foucault's major works, Madness and Civilization (1973), for example, "madness" is analyzed as a concept that emerged out of constructions of mental illness. In the present study, the circulation and repetitions of statements from environmentalist and communitarian discourses are conjoined with statements from "arboriculture" (tree care) and "community empowerment" in the formation of the professional discourses and structures of "urban forestry" and "community development." Fairclough (1992) explains that the discursive formation of concepts can be analyzed "through a description of how the 'field of statements' associated with it, in which its concepts 'appear[ed] and circulate[d]', is organized" (p. 46). Foucault describes this as "a space in which [statements] are used and repeated" (1972, p. 106); he therefore recommends a methodology for "the analysis of discursive formations [that] really is centred on a description of the statement in its specificity" (p.114). The statement exists peripherally and residually in discursive structures: its presence can be traced through the signs it leaves in texts. The analysis of co-existent "dispersed and heterogeneous statements" (p.34) thus aims to show how statements structure orders or mixings of discourses, and how these orders of discourse reflect social and political orders that are ultimately anterior to language.

\section{Recontextualization}

The statement is available for analysis as that element of discourse that can be reified because of its ideologically recognizable weight: it can be repeated in the contexts of other discourses where it will survive as a modified version of its former semantic and pragmatic force. The statement is

[a]n enunciative function that involve[s] various units [sometimes sentences, propositions, fragments of sentences, series or tables of signs, a set of propositions]; ... [and] opens up for them a number of possible 
subjective positions; instead of fixing their limits, it places them in a domain of ... coexistence; ... in a space in which they are used and repeated. (p.106)

It is "recognizable" outside its antecedent contexts, so that when it is repeated it retains something of its former meaning. This capacity for repeatability makes certain statements especially attractive and subject to importability into other discursive contexts. Although the statement "is endowed with a certain modifiable heaviness" (105), like the imported "words of others" that Bakhtin (1981) examines, this weight is also "subject to certain semantic changes" in its recontextualized existence (p. 340). Foucault's description of the appropriation of statements, consonant with Bakhtin's theory of dialogism, highlights the play between words as they are recontextualized: "there can be no statement that in one way or another does not actualize others" (Foucault, p. 98). In this way, the "repeatable features"

are in the power of the particular context in which the utterance is made; this context can refract, add to, or in some cases, even subtract from the amount and kind of meaning the utterance may be said to have when it is conceived only as a systematic manifestation independent of context. (Holquist paraphrasing Bakhtin, 1981, p. xxi)

For Bakhtin, recontextualization and dialogism have a social and ideological dimension: the reified but "living utterance ... cannot fail to brush up against thousands of living dialogic threads, woven by socio-ideological consciousness around the given object of an utterance" (p. 276). The heterogeneity of these statements exists as a feature of language itself; in Bakhtin's definition, language "is stratified ... into languages that are socio-ideological: languages of social groups, 'professional' and 'generic' languages, languages of generations and so forth" (p. 272). The ideological content of statements and utterances thus brings potential struggle into dialogical sites, and raises the issue of more or less dominant discourses.

The repeatability of approved language, specifically, received and privileged terms that construct the dominant ideology of its users, lends itself to importability into other documents when its terms are ritualized abstractions-as with the ideals in both global and civic discourse of environmental sustainability and citizen empowerment. This portability allows the terms of different ideologies to exist in a mixed contextual space, where both the earlier context and the new context collude or collide. The recontextualized statement arrives with a "psychological halo" (Foucault 1972, p. 98) - what Foucault describes as "the half silent murmur of another discourse" (27-28). As mixed and modifiable, for example, the statement informing terms such 
as "sustainable development" in United Nations reports can become reinstated as "sustainable community," "sustainable resources," and "sustainable economy" in subsequent management discourse. A potential conflict therefore can exist between statements from different discourses, here between the forces of environmental protection and the forces of economic development: "any utterance ... [is] a contradictionridden, tension-filled unity of two embattled tendencies in the life of language" (Bakhtin, 1981, p. 272).

Bakhtin's (1981) theory of dialogism and its implications for discursive ambivalence (Kristeva, 1980) and for the relationship between intertextuality and hegemony (Fairclough, 1992) provide important conceptual foundations for this study. Kristeva describes Bakhtinian "dialogue" "as a writing where one reads the other .... the notion of a 'person-subject of writing' becomes blurred, yielding to that of 'ambivalence of writing" (p. 68)."[T] he writer can use another's word, giving it a new meaning while retaining the meaning it already had. The result is a word with two significations: it becomes ambivalent" (p. 73). Ambivalence is described as the "co-existence" of heterogeneous statements "striv[ing] towards harmony" but "implying an idea of rupture" (pp. 88-89). Fairclough reprises this ever-present possibility of conflict: "Intertextuality is basically the property texts have of being full of snatches of other texts, which may be explicitly demarcated or merged in, and which the text may assimilate, contradict, ironically echo, and so forth" (1992, p. 84). Intertextuality "is the source of much of the ambivalence of texts" (p. 105). Fairclough thus proposes that the struggle signified by dialogical relations can be analyzed and "conceptualize [d] as intertextual processes and as processes of contesting and restructuring orders of discourse as processes of hegemonic struggle in the spheres of discourse" (p. 103).

\section{Interdiscursivity: The mixing of discourses}

In "The Discourse on Language" (1972, previously delivered in French as "L'ordre du discours"), Foucault refers to his project as the analysis of the "internal economy of discourse," and explains his break with the "traditional methods of exigesis" and "linguistic formalism" as a move "to describe," instead, "the transformations of a discourse, and its relations to the institution," to treat the history of a discourse not as a mere account of themes and concepts but as a an "ensemble" of discursive "instruments" (p. 235). "Ensemble" aptly describes a strategic mixing or ordering of discourses motivated by interest. In this study, following Foucault's description, the focus of analysis is on how different discourses historically "combine under particular social conditions to produce a new, complex discourse" (Fairclough, p. 4). Borrowing Foucault's concept of "the order of discourse," Fairclough suggests that discourse analysis should aim to examine the "structuring or 'articulatory' processes in the construc- 
tion of texts, and in the ... constitution of 'orders of discourse' (that is, total configurations of discursive practices in particular institutions, or ... a whole society)" (p. 9). The focus should be on interdiscursivity as "a matter of how a discourse type is constituted through a combination of elements of orders of discourse" (p. 118). Interdiscursivity is thus different from intertextuality in that the former "involves the relations between other discursive formations which ... constitute the rules of formation of a given discursive formation," whereas the latter involves "relations between texts" (p. 47). Rather than focusing exclusively on the text as artefact, the analysis of "the unity of a discourse" should be focused "on the space in which various objects emerge and are continuously transformed" (Foucault, 1972, p.32).

Some recent studies provide examples of how the mixing of discourses has been orchestrated strategically to serve specific political interests. In Fairclough and Wodak's study of Thatcherite rhetoric (1997), they analyze the transmutation of "thriving industries" into "thriving services" as "an innovation of an ideologically potent sort: to achieve a coherent meaning ... one needs to assume that services can be evaluated on the same basis as industries" (p. 276), an equivalence that the authors patently discredit. A second example comes from another study by Fairclough (2000) cited in an article on "management speak" by Jenkins (2002). In this example, the term, "inclusion," is shown to signify, paradoxically, social exclusion in certain politically motivated contexts:

The term "inclusion" has emerged as one of the most important signifiers of New Labour reconstruction encompassing the social, economic and educational spheres. But under New Labour "inclusion" has been reinterpreted as part of a coercive discourse and wider set of goals. An example from a speech by Tony Blair (1997) quoted in Fairclough (2000) illustrates a particular version of inclusion: ... . Social deprivation is seen as responsible for 'irretrievably sliding' Britain into 'division'. This embodies a discourse of panic, linking poverty, exclusion and crime to a threat to national interest and even sovereignty. In the Management Speak of New Labour, social and education agendas are joined in a project which implicitly or explicitly positions marginalized groups either as dependent victims or as being, or becoming, out of control. (p.

54)

The terms of an altruistic discourse have much symbolic capital and can be strategically appropriated into other discourses and documents to profit from their privilege. The influence of such "god" terms, the power of their mystification, has been 
analyzed by Burke (1966) for their capacity to create both identification (inviting agreement with an ideology) and division (opposing one ideology to another). When appropriated, such terms can activate the ideology that framed them in one discourse, but this emanating ideology is both transformed by and transforms its new context. An example can be drawn from this study. The environmentalist meaning of the term "sustainable" is transmuted through its recontextualization as "sustainable development," which has apparently been borrowed from more global discourse that gives it an economic accent. This economic connotation enables the rhetorical strategy of "balance": balance between development and green space, cost-effectiveness and conservation, and recreational access and ecological protection.

\section{Exclusionary discourse}

As the statements of discourses are appropriated into other, more dominant discourses, the features of the dominant style contribute to the eclipse of the interpretive force of the non-dominant discourses, not because of any power the features themselves possess (for example, the passive voice can be innocuous or devious), but because they are used strategically in the interests of a dominant power which can exert its force to seduce and co-opt opposing forces. Managerial discourse, for example, can have effects at two levels: the textual or stylistic, and the political level outside of discourse. Textual features of the managerial style may convey an impersonal, objective, and exclusionary ethos. This exclusionary, "objectivist" style often characterizes bureaucratic and administrative discourses in general. Of particular relevance to this study is Killingsworth and Palmer's rhetorical and stylistic analysis of scientific research discourse as resistant to "intrusions from forces outside the community" (1992, p. 99), specifically environmentalist values. Many of the features of this style overlap with those found in managerial discourse, with the overall effect of creating a distance between government and community. The features Killingsworth and Palmer found include a reductiveness that focuses on technical rather than moral issues, the elimination or folding in of conflict, the primary motivation of "control" and "selfperpetuation" (p. 13), a championing of democracy and an "informed citizenry" (p. 80 ), an emphasis on "instrumental" or regulatory action as opposed to "communicative" action (pp. 166-67), and objectivist features at the grammatical level (for example the strategic use of agency to serve managerial interests).

As this study will show, although the NAMP was written for Parks staff, staff in other city departments, and ostensibly for the community at large, the style of the plan seems to limit accessibility rather than invite the broader community. It will be argued that this limited accessibility is an effect of the surviving dominance of managerial discourse which overall seems to neutralize environmentalist and 
communitarian discourses, and privilege economic discourse. Since power motivates the uses of ideology in discourses, this process can be neither "neutral" nor "consensual," but is instead a matter of ideological struggle. Power is not static; "rather, it is produced through the co-optation of an organization's system of signification by sectional interests" (Mumby, 1988 p. 83). In his work on managerial ideology, for example, Mumby proposes that

[i]t is no accident ... that in organizations the managerial interest most frequently characterizes the framing of organizational reality. ... the managerial interest is powerful enough to control the ways in which other interests perceive what is good, possible, and so forth. Alternative views of reality generally emerge and are perceived as legitimate only when a certain group can structure the communication in a way that articulates a compelling view of society, the organization, et cetera. (p. 93)

Appropriating altruistic discourses into management discourse might be a particularly effective strategy for creating a "compelling view" of initiatives that primarily serve economic imperatives. The contradictions in such a mix of discourses will often be mystified or concealed through the naturalizing effect of a dominant ideology for those whose interests will be served (Mumby, p. 74). The contradictions of co-existent discourses may not be recognized by insiders whose desire constructs them as "seamless" (Fairclough, 1992, p. 97) through a sort of institutional myopia. According to Giddens (1984), when ideology represents sectional interests as universal, it becomes hegemonic, for it involves the articulation of the interests of others as its own interests (p. 86). Recontextualilzations that deploy different discourses and result in contradictions can be denied or transmuted by ideology. For example, the NAMP black-boxes and defers to a future date the important task of writing natural areas policy, so that there is a textual silence, a kind of denial of the unsympathetic but clearly anticipated response from the developmentalist lobby.

\section{Methodology}

The research methodology for this study has been designed to generate both textual and contextual data and information. The ground for the collection and interpretation of data for the study was the development of a participant-observer relationship with the management and staff of a municipal Parks and Recreation department. This ethnographic approach has been combined with other qualitative methods-observations of meetings, interviews, focus groups, questionnaires, and textual analyses of relevant documents. ${ }^{2}$ My relationship with Parks and Recreation staff and others involved in the natural areas project began first in my capacity as a consultant 
when, in the summer of 2000,1 was hired to revise and edit the NAMP. Once this work was completed, in early 2001,1 assumed a strictly researcher role. I worked with the project manager, his staff, and the natural areas project steering committee, and I had access to a number of other managers in the division. I made observations at both their informal discussions and formal meetings over a period of three years, and attended the city council meeting where the NAMP was enthusiastically received. This paper is a product of the second phase of research at this site; the third phase involved the collaborative development of public policy from the NAMP. (See Figure 1 below for a simplified chronology of the project.)

The documents studied for this paper were identified and supplied by Parks department staff. They enabled a reconstruction of the chronology of the project and the processes of recontextualization of the key terms of the different discourses that were appropriated from document to document. Key to this study were a number of antecedent documents produced by the UN on the environment, conference papers, arborist and urban forest professional literature, professional literature on the "community development" model, foundational city documents (such as Master Plans), and Parks and Recreation management reports, plans and other routine documents. In addition, management reports from other cities, which were identified as background materials by managers, included a natural areas plan for a city in another Canadian province, an access and recreation plan for an American city, and the "Street Tree Master Plan" for another city in British Columbia.

Qualitative data was also collected from 15 questionnaires, 14 interviews (four of which were audio-taped), a focus group of managers (also taped), written observations of two internal steering committee meetings and one urban forest advisory committee meeting. Participants in the study included both internal managers and staff (city) and external community residents.

Internal:

- Parks Commissioner

- Manager of the Parks Department

- Manager of Planning, Research and Design

- Manager of Park Development

- Manager of Business Operations and Athletic Fields

- Two Managers of Parks Operations

- Manager of the Urban Forest and Environmental Services Section (project manager)

- Two Urban Forest Technicians

- Environmental Education Coordinator 
External:

- Three members of Advisory Committees (Residents)

- Two provincial Forest Protection Officers

- Chief Fire Prevention Officer of the city's fire department

\section{Background}

The NAMP has a comprehensive overview of 33 pages, appended with seven detailed implementation strategies ranging in length from 19 to 55 pages (see Appendix 1 for the table of contents of the plan). One of the first of its kind, it sets out principles, objectives, and proposed policy for protecting and managing the considerable green space still existing in the municipality. Those directing the project were of an arborist and urban forest background and committed to protecting the remaining green space in the city. According to the manager of the Parks Department, the plan encompasses "all natural areas within parklands and other lands administered by Parks and Recreation, including leased lands and provincial lands under the care and control of the City."

The seeds of the plan were sown in the early 1990 s by the past and the current managers of the Parks Department, who each drafted outlines for an Urban Forest Management Policy. These outlines were superceded by a draft outline for an Urban Forest Management Plan, proposed by the current manager of parks. In June 1995, parks managers drew up terms of reference for an Urban Forest Task Force, the scope of which was to be limited to the two designated urban forests in the city. In June 1996, the vice-chair of the task force presented a seven page report to the Parks Commission. From 1998-1999, the urban forest technician and environmental education programs coordinator worked on a revised and expanded version of the plan, [The City's] Urban Forest, Wildland and Tree Management Plan. Over the following year, different components were assigned to staff and consultants, and in the summer of

\section{Figure 1. Chronological Overview of the Natural Areas Management Project.}

\begin{tabular}{cccc}
\hline 1992 & $1995-1996$ & $2000-2001$ & $2002-2003$ \\
PARK & TASK FORCE & STEERING CTE & POLICY CTE \\
MANAGERS & $\begin{array}{c}\text { (urban forests } \\
\text { policy) }\end{array}$ & (natural areas) & $\begin{array}{c}\text { (natural areas } \\
\text { policy) }\end{array}$ \\
\hline
\end{tabular}


2000, the author was hired as a writing consultant to help organize and edit the plan. In 2002, a sub-committee was struck to develop natural areas management policy (see Figure 1).

\section{Results and discussion}

In the following discussion, the first section explores the context of the natural areas project through the commentary from project participants. This is followed by an analysis of typical examples of those key terms reflecting the ideology of different discourses as they are appropriated and repeated. These examples are drawn from a series of salient global and professional documents. The next section then provides an analysis of appropriations of these terms and the mixings of discourses in municipal management documents, focusing ultimately on the NAMP. Two more sections discuss the effects of the NAMP project, first for its exclusionary effects, in terms of both its textual style and contextual issues of excluded participation, and second for its pragmatic effects within the Parks and Recreation department.

\section{Participants' values}

On the surface of it, participants' comments in questionnaires, interviews and meetings reflect the predominant ideological discourses of environmental protection and the communitarian value of public participation and empowerment in public processes and activities. A brief description of each key participant group-managers, staff, and advisory committee members-attests to this strong common ground that they shared.

Overall, managers' comments often evoked topics related to the protection of the environment and natural areas, and to the involvement of the community in this effort; comments were sometimes modulated by references to management, budget, and access and recreation. Some managers have been engaged in the process of educating others, who have historically had a more traditional philosophy of parks management as mostly a matter of landscaping, individual tree care, and managing the public. For example, one operations manager still sees his responsibilities as ensuring that the public is informed and that only permitted activities occur in natural areashe calls this work the "meat and potatoes in the real field." The overall manager of the Parks division is strongly invested in an environmentalist agenda, but he sees in his job the additional responsibility to satisfy certain political and economic realities. One of his key motivations is to use the NAMP to develop policy so that the department can cite official support in the event of opposition: "I will be the guy standing in front of policy bodies making 'the pitch' or defending our actions." The project manager also sounds a cautionary note, though from a slightly different perspective. $\mathrm{He}$ 
sees the city as a "civic leader" in natural areas management, and opposes the "any development is good development" attitude he attributes to the current Council. He regrets the omission of "provision standards" for land protection in the plan (the setting of minimal amounts of land to be acquired or reclaimed annually by the city for green space). The two senior staff who participated are both of a younger generation than most managers and are explicitly committed to the environmental values of the city's natural areas. These newcomers, the technician and education coordinator, see themselves as advocates for the protection of natural areas.

Those community members of urban forest advisory committees who participated in the project are seriously committed to environmental protection, and have been involved in activist strategies to protect the forests. Both chairs of the two advisory committees had actively organized grass-roots campaigns in the 1980's and successfully challenged city hall's plans for developing forests in their communities. They personally patrol the forests for any threats to their health and have received awards of distinction for their work, including the Queen's Golden Jubilee Medal in 2002. (For a summary of participants' conceptions of priorities and values, see Appendix 2.)

In addition to environmentalist values, all participants also emphasized the importance of community participation, though from their different perspectives and for different reasons. Managers expressed commitment to the city's widely articulated goal of "community development," to be realized through citizen participation and volunteerism; senior staff emphasized liaison and communication between the city and its residents; and advisory committee members had in mind the rights of citizens to participate in government decisions, and to advocate for contentious issues.

\section{The mixing of discourses}

Various discursive antecedents and appropriations of altruistic language emanate from the statements that foster the language of "environmentalism" and "community participation and empowerment," and come to permeate the management plan. The discussion here examines textual evidence of altruistic language cohering around a number of recurrent key words, phrases and values. The appropriations show a conflation and interchangeability of terms as they are repeated in different contexts. One typical cluster includes "environmental sustainability," "sustainable development/ cities/ economy," "urban forests," "urban communities", and "environmental stewardship." Similarly, and concurrently, communitarian discourse is located in such phrases as "community development," community participation," community empowerment," "citizen participation," "empowered/responsible citizens," "vol- 
unteers," and "stewards." These appropriations and mixing of the altruistic discourses of environmentalism and communitarianism can be traced to discourses of economics and management. The texts analyzed below are a collection of documents, ranging from the global to the municipal, and are traced in three ways: appropriations of altruistic discourse (1) from global into professional documents, (2) from global and professional into municipal documents, and (3) from these antecedent documents into the NAMP itself.

\section{Antecedent global and professional uses of altruistic rhetoric}

Parks managers and urban forestry staff have made frequent reference to the Dictionary of Natural Resource Management (1996) for its authoritative and environmentalist definition of "sustainability": "the ability of an ecosystem to maintain ecological processes and functions, biological diversity, and productivity over time" (p. 308). Significantly, "productivity" is in no way linked with any economic motivation, though one could argue it may be incipient. Equally significantly, the authors reserve a separate entry for "sustainable development":

A conceptual ideal where development ... meets the needs of the present generations without compromising the ability of future generations to meet their own needs.... the concept may be unrealistic .... However, as a concept it has made some profound changes in the attitudes as to how these finite resources are being developed. (p. 308) (itals. mine)

The assertion that the concept "may be unrealistic" might imply that economic motivations prevail over environmental protection.

The globally influential United Nations document, The Brundtland Report: Our Common Future (1987), helped make "sustainable development" into a catch-phrase: "There is still time to save species and their ecosystems. It is an indispensable prerequisite for sustainable development. Our failure to do so will not be forgiven by future generations" (p. 166). The repeatability of this phrase, and its frequent substitution for "environmental sustainability" in environmentalist discourse, created the conditions for the now prevalent economic interpretation of "sustainable development." Environmentalist discourse, in governmental and industrial contexts, has become increasingly associated with the discourse of economics. For example, a conference paper presented at the North American Forestry Commission ... of the United Nations (2000) links "sustainable urban ecosystems with "dollars expended": "Sustainable urban ecosystems are landscapes designed ... to minimize impact on the environment and maximize the value received for the dollars expended in the long term" (McPherson, 2000, p. 6) (itals. mine). Similarly, a conference paper on the "management of green 
areas," presented in Mexico City (2000), combines these discourses, recommending measures to "improve these green areas and increase their financial self-sufficiency" and to "create a more sustainable source of funding" (p. 11-12) (itals. mine). At the provincial level in Canada, similar examples from managerial discourse appear, as in the following excerpt from a provincial government's report, An Economic Framework for Sustainability (B.C., 1993):

We must develop ways to incorporate values that have, until now, been excluded from the array of relevant costs and benefits... This [proposed] strategy would be based on a collective vision of a sustainable future, ecological and social realities, a new process of decision-making, and the identification of strategy priorities. (P. 11) (itals. mine)

Here "costs and benefits" become associated with a "sustainable" ecology. Killingsworth and Palmer (1992) also note the appropriation of "sustainable development" by developers and industry, and point out the difference between the early focus on the environment (for example, Lester Brown's Building a Sustainable Society, 1981) and the now almost universal focus on people and socio-economic needs (p. 239).

In UN sources the goal of environmental sustainability is often promoted in terms of responsibility at the local or community level and becomes mixed with the communitarian discourse of community development and participation: "Each local authority should enter into a dialogue with its citizens, ... [and] adopt a local community environmental and developmental action plan particularly suited to local problems" (United Nations, Guide to Agenda 21, p. 100). The same mix occurs in governmental and professional documents. In an American Department of Agriculture report, a number of versions of this conflation occur, for example, "community forestry," "sustainable communities," and "sustainability and community vitality" (Urban and Community Forestry on Course Into the Future: Vital Communities Through Healthy Ecosystems-A Strategic Direction, October 1995). And, just as environmentalist discourse in its earlier instantiations became mixed with the discourse of economics, the discourses of environmentalism and community development now appear together with economic motivations. For example, in another conference paper, this one presented in Los Angeles, we find clusters of phrases incorporating all three discourses; for example, "environmental and economic sustainability" appears with phrases like "empowered citizenry," "cost-benefits analysis," and "benefits of . . e economic development" (Lipkis, 2000, p. 13) (itals. mine). We also see here the shift from what was "sustainable development" to "economic sustainability" and "economic development." 
The mixing of these discourses in managerial and professional documents becomes politically motivated (Fairclough \& Wodak, 1997), as it enables the co-presence of two different professional streams: arboriculture or "tree care" (to become associated with environmental sustainability and the profession of urban forestry) and community development (to become associated with environmental stewardship and volunteerism, and the professional community development officer). Both of these come into the discourse and structures of the Parks department and the NAMP plan and project.

In the case of urban forestry, the definition of its antecedent, "aboriculture," underwent a sea-change in the 1990s. Managers and staff identified a prominent textbook in the field as an important influence in this change. Two editions of the textbook, 1992 and 1999, illustrate the shift in the scope of the field from primarily "trees" (1992) to "assemblages of trees" and "urban forests" (1999):

Arboriculture ... is primarily concerned with the planting and care of trees and more peripherally concerned with shrubs and woody vines and ground-cover plants.... A company ... may engage in landscape design, nursery production, and all phases of landscape horticulture. Another may specialize in one of two. (Harris, 1992, Arboriculture: Integrated Management of Landscape Trees, Shrubs, and Vines, p. 3) (itals. mine)

... arboriculture focuses on tree care activities applied to individual trees and small groups of trees. Urban forestry, in contrast, focuses on the management of assemblages of trees, employing both traditional aboricultural practices as well as forestry ... treatments. Rather than try to split the two fields along artificial lines, we embrace the overlap between the two... Many arborists consider themselves urban foresters, and vice versa. (1999, p. 7) (itals. mine)

The backdrop of environmentalism is tacit and profound in the profession. When queried about the environmentalist influence on changes in the profession, a recently hired urban forest technician explained that "global awareness just trickles down to the municipal level." The manager of Parks added that this trickle-down effect occurs through professionals who have an influence on urban forestry through conferences and publications: "then Parks and Recreation applies it to the natural areas at the municipal level." 
In the second stream of professional discourse, "community development," its most idealized versions are associated with "democracy" and "empowerment." For example, on the final page of a Canadian handbook on "community development," there appears a quotation from Alex de Tocqueville, linking citizen "functions" to democracy: "The health of a democratic society may be measured by the quality of functions performed by private citizens" (Herchmer,1996). Similarly, in the 2001 edition of the report from the International Centre for Sustainable Cities, the Canadian guest-author suggests "that public participation's roots can be tracked back to the direct democracy of ancient Athens" (p. 2). In many such documents, inserted into the articulation of this ideal are the goal of "empowerment" and the role of the municipality as "facilitator." A federal handbook on community development cites Paulo Freire: "Empowerment embodies a broad process that encompasses prevention as well as other goals of community connectedness, self development, improved quality of life and social justice" (p. 5-25).

In 1986, an article in the journal, Recreation Canada, recommends that parks and recreation departments be responsible for community development initiatives: "the major role of municipal recreation department community development workers [is] to facilitate ... advisory councils ... assist their own municipal departments ... and work with powerless groups" (Ward, 1986, pp. 7-8). This particular source was appended to a major Parks department report for the city (1994) on how and why all parks initiatives are to incorporate the practice of community development. The Parks department report itself is laden with the language of "community," "citizenry," and "empowerment." "By undertaking a philosophy of community development as the framework for policy and practice, the Parks and Recreation Department could encourage a return to 'citizenship'-responsible participation in issues that affect citizens-at the grassroots level" (Community Development Task Force Report, p. 1). Notably, the economic motive is also present in this document: "community development' requires a paradigm shift from the role of Parks and Recreation as provider to the role ... as facilitator" (p. 1). In a later article in Recreation Canada (1990), "Empowering the Citizen: Advocacy for Recreation and Parks," parks staff are urged to advocate for citizen involvement and empowerment as a professional responsibility.

These two professional streams, the discourses of urban forestry and community development, become elaborated and conjoined in conference papers and publications in the emergent field of urban forestry, which increasingly incorporates an economic motive. For example, an international conference paper (2000) (cited earlier) yields a typical formulation: 
In North America the urban and community forestry paradigm is shifting from a focus on beautification to one that encompasses all of the environment... [as] natural capital vital to sustaining quality of life in our growing communities. Livable communities are economically powerful communities... (MacPherson, pp. 4-6) (itals mine)

In the position statement of the Society of American Foresters (1997), we find the same mixing of discourses. In textual association with the assertion that, "Urban forests and tree programs ... deserve our sustained support" (p. 2) are the phrases, "community strengthening," "community forestry," "sustainable management," "citizens," and "partnerships" (pp. 1-3). The term "partnerships" seems to be coded with economic motivations, as in the strategy of developing "private and public partnerships," currently promoted by governments and intended to signal a partnership of mutual financial investment.

\section{Municipal uses of altruistic statements: a similar mix}

The conflation of the discourses of environmentalism and community development also occur in municipal documents, both in Canada and the United States. For example, from a city in California, a strategic document, Goals for Community Forest Programs (1999) associates "sustainability of [the city's] arboreal environment" and the protection of "community trees" with "community support" and internal city support from "your own community" (that is, arborists, city staff, parks and recreation staff), and with "efficient and cost-effective management of the urban forests" (p. 1). Similarly, in the Natural Area Management Plan (1994) for another Canadian city, environmental stewardship is depicted in terms of how citizens can contribute to "natural environment parks maintenance" through activities such as "communitybased cleanup" and "community communication and training" (pp. 90-91). The plan stipulates that "staff are no longer the only method of delivery as community groups ... are committing greater amounts of time and funds" (p. 91). Another Canadian city cites a typical formulation in its Urban Forestry Management Plan. In the following excerpt, "preserve" and "environmental" occur with "manage" and "economic benefits":

[Our mission is] to preserve, manage and enhance trees and vegetation and to promote reforestation ... for ... aesthetic, environmental and economic benefits. (Urban Forestry Master Plan: Mission Statement and Goals, 1996/97). (itals. mine) 
At the municipal research site studied for this paper, foundational city documents show the same use and co-occurrence of environmentalist, community development, and economic discourses. In an environmental assessment report, developed in consultation with urban forest advisory committee members (1998), the dominant discourse is environmentalist with typical topics as follows: "wildlife, diversity of habitat, mammal trapping, road kill, high environmental sensitivity, species, fragmentation, retreat of mammals" (Environmental Overview and Assessment of Proposed Road Improvements at ... Urban Forest). In other Parks department documents, the discourse of "community development" is also salient:

... the recommendations in the following pages would seed the transformation of Parks and Recreation from an organization that works for the community to provide services ... to one that works with the community towards the evolution of its desired future. (Strategic Organizational Review Team (SORT): Community Development Task Force Report, Department of Parks and Recreation, 1994, p.1)

[The report] provides the foundation for further developing a sustainable approach that involves community in the process of growth and change allowing for their participation ... [and] sustainable programs in support of a safe and vibrant parks system (Community Development and Partners in Parks Programs: Summary Report, Fall 2001, p. 20)

[Community development is] a process of meaningful community participation ... also a process in facilitating community capacity and empowerment in the evolution of community. (Directional Document for Community Development, Parks and Recreation, October 2001, p. 1)

...old models of service delivery will need to change to approaches that genuinely involve and empower community members.... moving away from a top-down service delivery model, .... to take significant steps towards a community development approach. (Active Living through Community Development: Building a Community Development Team. July 1995, ... Leisure and Parks Services, by a consultant, p. 3)

The familiar repeated terms of environmentalist discourse tend to increasingly occur in association with the economic concern of cost-effectiveness. The economic motive is explicit in the Parks department proposal for a cost-effective community develop- 
ment model, submitted to an ultra-conservative BC think tank, The Fraser Institute:

The proposal recommends that civic governments adopt a new service delivery model - ... the "Community Development Model"- as an innovative vehicle for reducing service delivery costs, increasing efficiency, and enhancing customer service .... civic government would change its emphasis from directly providing programs and services to that of facilitating local initiatives through groups and existing agencies to provide those services for themselves." (Proposal: Community Development Model, submitted to The 1995-96 Fraser Institute/Financial Post Economy In Government Competition, submitted by The City of . . , Parks and Recreation Department, December 15, 1995, p. 1)

Included in this proposal is a quotation from an article in the Journal of Public Health (Chodorkoff, 1989), "Social Ecology and Community Development," that utilizes the trope of "social ecology" in association with an economically driven definition of "community development." The author states that community development is not "the delivery of services to a needy population by professionals. Nor is it bureaucratic intervention on a massive scale ... This approach fosters dependency ... It can lead to the dis-empowerment of communities and citizens, not their development" $(71)$.

Similarly, in the city's Official Community Plan (1996), the focal goal of the "land use strategy" is mixed with the altruistic terms of "community" and "sustainability": key phrases include "development and acquisition of land," "economical development," "community involvement," and "sustainable communities" (pp.1-2). The city's 1998 Update: Report Card on the Master Plan (1996) notes that, given the current "investment and development climate," "[The City's] Development Advisory Committee," is "concerned about the "amount of urban forest" that is protected and about the current "park and open space standards" (p. 12). It reports favourably on "community development" and promotes the economically motivated shift from "being direct providers to being community facilitators" (16), as well as the need to pursue "public/private joint ventures" (p. 18). Furthermore, in the vocabulary of "customers" and "business," the city's Parks and Recreation 1996-2000 Marketing Plan promotes "the highest corporate sponsorship and return on investment" (p. 1). These goals are presented as part of the "city's mandate," which includes "protecting the natural environment" (p. 5). 


\section{The Dominance of Managerial Discourse in the Natural Areas Management Plan}

The NAMP itself is heavy with environmentalist and community development language. The vocabulary of environmentalism has a strong presence in the plan: presuppositions indicating assumed shared values are present in references to "ecosystems," "biodiversity" and "environmental sustainability" (p. 9). The terms of this discourse appear in such formulations as "sustainable environment," but are also inflected as "sustainable development" and "sustainable future" (p.9). And the terms of three discourses are again salient:

environmentalist: natural areas, biodiversity, environmental sustainability, stewardship, ecosystems, ecosensitive, sustainable community, wildlife, threatened/endangered/extirpated [species]

community development: community development, community ownership, community responsibility, community participation, community relationships, public participation, volunteers

economics: economic development, cost effectiveness, corporate partnerships, climate of decreasing government funding, challenging financial climate, economic development of the City, preservation of property values, alternative funding sources

A significant rhetorical strategy of the NAMP is based on the ethical appeal of "balance," which situates environmental protection and human needs for "development" on the same level of value. For example, the plan advocates the "protection of the natural environment in balance with economic development" (10). Balance becomes the basic rationale for the plan:

A number of factors related to rapid development and urbanization of [the city] now threaten its natural areas and give rise to questions of balance between ecology and human activity. (p. 11)

The Parks Division has undertaken to develop its management plan to address these issues by adopting a balanced approach — and to carry out its plan in a climate of decreasing government funding. (p. 11) 
Phrases like "park natural areas," "diversity," "sustainability," "stewardship," and "sustainable approach" occur with statements that reflect management interests: the parks department will "manage and intervene to achieve sustainability"; staff will enable "access and recreational uses... without compromising sustainability" (p. 6). In this way, the economic motive is mixed with aspirations to community development and environmental protection. It appears in recommendations to capitalize on the use of green spaces through "eco-tourism" and initiatives to draw more "tourists" into the city. These mixings seem intended to serve a predominantly economic interpretation of how to manage natural areas: to "reduce costs," "increase liveability and socioeconomic values," and "assist the City's economic development" (17). It would seem that the mixing of these discourses and the move to give economic (development) interests equal value to environmental interests, on the sheer strength of managerial and institutional power, can more or less neutralize the altruistic implications of the discourses of environmentalism and communitarianism.

\section{The Exclusionary Effects of Managerial Discourse in the Natural Areas Management Plan}

The NAMP project resulted in certain exclusionary effects: some of these are textually produced through the features of a managerial style, and some have been produced through the contextual, material processes of developing the project. These exclusions are consistent with and related to the diminution of altruistic intentions as described in the previous section.

\section{In the written text:}

A brief textual analysis of NAMP for the features of an objectivist style suggests that managerial discourse has a strong tendency to be exclusionary of those readers who are anticipated to be non-compliant, yet who are claimed to be part of the plan's audience. This disclaimed exclusion reinforces the effect of ambivalence. The style is essentially one of limited accessibility, with features that one might predict: management jargon ("principles," "strategic directions," "themes," facilitation," "thrusts," "resource management techniques," "in-house steering committee," "stakeholders"); directives, in both the active voice ("implement," "develop," acquire," identify") and the passive voice ("should be undertaken/implemented/pursued"); nominalizations and noun strings ("publicly inclusive conflict resolution processes," "adoption of a community development service delivery model"); and repetitive structures ( parallelism and list format) (Killingsworth \& Palmer, 1992, pp. 173-179). A few extended examples are as follows: 
(1) The primary strategic direction is to provide for safe use, reduced corporate liability and maximum benefits possible to park natural area ecosystems:

- Implement a comprehensive tree hazard management program that will effectively protect park patrons and address City liability

- Prescribe hazard tree abatement work that meets industry standards and, where possible, contributes to the ecological health of natural areas (p. 7 )

(2) Publicly inclusive conflict resolution processes should be undertaken, to ensure the principles ... of the Natural Areas Management Plan are fully considered in decision-making. (p. 18)

These features facilitate communication where managers are addressing other managers and insiders, but when a management document enters the public domain such features can discourage reader "identification," that is "the means by which a speaker or writer puts forth an image or character ... and invites the audience to participate. in a consubstantial relationship with that image" (Killingsworth \& Palmer, paraphrasing Burke, 1992, p. 23).

Other stylistic features also limit accessibility and reduce the range of rhetorical effects. These include the creation of a sense of urgency, the use of a corporate model, the implication of expert authority, and the use of agency to favour managerial perspectives. Differences (and conflicts) between the audiences invoked and real readers can be folded into the discourse and mystified or ignored; in this case, they city's diverse residents and their various community groups are removed from the surface of the language of the plan. Ordinary readers are neither addressed nor accommodated.

A moderate sense of urgency can further override differences and help construct an assumption of consensus. In the following excerpt, for example, a sense of impending crisis in term of the community's need for access to green space helps pave the way for acceptance of "development":

A number of factors related to rapid development and urbanization of [the city] now threaten its natural areas and give rise to questions of balance between ecology and human activity. Between 1989 and 1999 the population of the City grew from approximately 220,000 to 
$325,000 . .$. Many natural areas are now bordered immediately by housing, commercial and industry developments: they are in serious need of stepped-up measures for both protection and access. (p. 11) (itals. mine)

This passage also highlights how the term, "development," has come to signify in two ways: with connotations of sustainable development in references to "ecology" and "protection and access," and with connotations of economic growth in references to "housing, commercial and industry developments."

The corporate model and the agency and authority of the expert are also features of the objectivist style. In manager "talk" and foundational documents, the City is referred to as a "corporation"; in the natural areas plan its community members are variously referred to as "stakeholders," "users," and "patrons." In the plan, there is a frequent lack of agency where typical subjects or topics are "decisions," "the plan" or "direction." Where there is agency, it is primarily on the management side and often conveys expertise: "the City, Council, Parks Commission, Parks Department, administration, Urban Forest and Environmental Service Section, decision-makers, [and] natural area managers," as in the following examples:

natural area managers must increase communication among stakeholders ... increase community ownership and community responsibility for natural areas. (p. 5)

the City has placed livability and protection of the natural environment in balance with economic development. (p. 10)

The Parks Division has accepted the primary environmental leadership role within the Department. (p. 10)

Other community members are presented as:

(1) objects to be acted upon: "educate the public on the impact of dumping" and "[change] public perceptions and attitudes";

(2) "people reduced to their productive functions" (Killingsworth and Palmer, p. 179): "users, patrons, stakeholders," (usually without agency, as in "[the] plans ... should address the health and safety of park patrons" (p. 16); 
(3) explicitly responsible for bad behaviour: with agency, as in "Residents and commercial and industrial contractors often opt for illegal dumping" (p. 29), and in directives without agency, as in "Utilize existing regulations and by-laws to fine and prosecute offenders" (p.30);

(4) implicitly guilty for "fires that are deliberately set," the "disposal of unwanted refuse," and "unauthorized trails"; or

(5) responsible for "user conflicts": "dog owners, cyclists, [and] pedestrians."

Other references to community members include "the general public," "other agencies," and "human traffic." Like the language of the environmental impact statement studied by Killingsworth and Palmer, (1992) the NAMP often conveys an ethos of authority that "nullifies potential identifications with the ordinary reader" (p. 171).

The rhetoric of authority and expertise projects the competence to control the limited sphere of the city's parks just as it delimits the sphere of audience accessibility. It is not an open system even though it promotes community participation as a goal (pp. 273-278). This style of limited audience accessibility also serves the increasing ascendance of economic motivations in mixes of managerial and altruistic discourses. As a result, a certain ambivalence characterizes the plan: it conveys good intentions and posits community involvement and environmental protection, but at the same time hesitates to address this readership, whether as partners or as opponents.

\section{In the context}

This textual ambivalence is congruent with comments from participants. On the one hand, as shown earlier, among participants community development and environmental protection are highly held values, and are still important goals to be achieved. On the other hand, they agree to defer addressing any shortcomings in achieving these goals in any direct way in the written plan, as a kind of "black box" response to their anticipations of a negative reception from the development side of the city. One manager acknowledges that the concept of community development is still "embraced unevenly throughout the Parks and Recreation" department. Another manager indicates that the committee developing policy from the natural areas plan is a "higher-level" and "philosophical" enterprise that need not be "pluralistic" or have "broad representation." And other motivations for the plan sometimes surface, here with the suggestion that the community will be consulted mainly when political exigencies develop: "elements of the Natural Areas Management Plan will be brought in to the community when there is conflict, a desire for improvement, or for planning 
parks." One member of the steering committee said she was "disappointed" that "users and residents had not been involved"; she "wished for more community involvement." One advisory committee member believes that the process neither recognized nor included the ethnic and linguistic diversity of the city: "We haven't made a great effort to reach out to them [their leaders]" or to translate the plan. References have also been made to the decision to exclude external representatives during the internal phase of "community development" which stipulates "restricted and limited public input" (Community Development Task Force Report, p. 7). "Both the project manager and parks manager have informally registered an acknowledgement that they would have liked more community input, and they hope that by now making the document public through strategic presentations they can facilitate community "buy-in."

It should be stated that the plan did have significant input and endorsement from the two urban forest advisory groups who were asked to participate. Members were mostly educated, retired, forest and wildlife professionals whose own educated and privileged "idiom" is "signified in [the] idiom" that "dominates" the language used at project meetings and in the plan (Lyotard, 1983, p. 9). In both idioms, syntax and vocabulary are sophisticated (see committee members' comments in next section). On the other hand, although other community groups are included under the very general terms of "residents" and "users," they are not addressed with any identifying signifier - they are cast as "other' in the report, as "diverse" or "ethnic populations," for example, or as "users," "residents with disabilities," or "offenders." In Habermas' terms, the document is strong on "instrumental" action (to regulate people and resources), but weak on "communicative action" (to create public participation) (in Killingsworth \& Palmer, 1992, pp. 166-181).

Such exclusionary effects have predictably been the subject of criticism. For example, in an article on "community management" (the term of currency in British versions of communitarian discourse), Darcy (2002) points out that it is the nature of management itself to pursue efficiency and technique as primary over social concerns:

...community management must ultimately be measured by external efficiency criteria, because that's what 'management' implies. 'Management," like bureaucracy, is a discourse about the rational pursuit of efficiency-but its rationality is divorced from questions of politics or social value, allowing ... the replacement of substance with technique. (p. 38 ) 
He depicts the problem as one involving the co-existence of discourses as a power struggle, here realized as an opposition between the state, as "dominant," and the community, as "co-opted":

effectively the ideal of "community" has been colonized and co-opted by the dominant bureaucratic discourses of the state and the associated practices of public administration. (p. 36)

A second significant exclusionary effect also emerges. In the NAMP, the prodevelopment audience has been patently excluded. Various managers have expressed concern about the development lobby within the city's governance, sometimes parodying its stance: "any development is good development," and sometimes reporting it directly: "The city's plan is to accelerate industrial and commercial development." The insertion of economic considerations in the NAMP anticipates opposition from the city's Development Advisory Committee, yet the plan avoids mention or address of this readership, even though clearly the plan's goals are at odds with the city's pro-development agenda. In Iedema's study of how recontextualization can formalize discourse and effect closure (1999), he reports a similar textual elision of genuine struggle:

the interactional manoeuvring and the power relational struggles are excluded from [the] written version.... [which] enshrines the consensus as unproblematic, impersonal and durable, naturalizing the interactional relations and power claims as... "mere background." (p. 58)

Instead of addressing conflict, the plan reiterates the theme of balance between environmental and human needs, and indirectly gestures towards developers, claiming that the plan's recommendations "will support the preservation of property values, increase liveability and socio-economic values, and assist the City's economic development" (P. 17). The steering committee has acknowledged that "the land use issue will come up": that "the unchanging problem is selling this into the other side of the city" (the development side). Advisory committee members and consultants also expressed similar concerns about development, though, unlike managers, they used the more confrontational and direct language of "ecospeak":

"I sense the malign influence on council of wealthy developers." There has to be ... limits on development." We need to "spell out" that we "cannot go on developing ad infinitum." "The city needs to take a stand." 
"However, there are challenges ... and potential, real conflicts. It is difficult to expand access and recreation and put people into a natural area and keep its ecological integrity. Can [the city] do this and keep real natural areas? These are tough decisions."

"It is unclear what is meant by the City seeking a balance between environment protection and economic development. Is this a hint that deletion of land for urban development is a possibility?"

Items from local newspaper articles seem to corroborate their concern. The pro-development agenda is represented as practically a fait accomplis.

A new Official Community Plan for the City of $[\mathrm{x}]$ has been given tentative approval by council. The new vision encourages more industrial and commercial development through revised land use policies. . A civic report states the city has enough land to accommodate new residential growth for the next seven to 12 years... The aim is for business development between 2000 and 2009 to double that of 1990 to 1999 and to accelerate new business development between 2010 and 2021, getting $\$ 2.5$ to $\$ 3$ billion in building permits. ... To achieve the goals, the city needs 1,000 acres of additional industrial land, a 20 per cent increase in the industrial land base, 500 acres of additional commercial land and a 37 per cent increase in the commercial land base, according to the report. . . A public hearing will take place on Dec. 10 to discuss the new OCP policies before council considers final approval. ("New OCP big on business, industry," [City] Now, Dec. 1/o1, p. 17)

Skeptics flooded the first in a series of meetings staged to figure out what to do with a massive swath of under-developed land east of Highway $55 . .$. "They're not even asking 'Do you want any development.' It's 'What kind of development do you want?"... [the city's] senior planner assured no decisions have been made about the land, but admitted it could play a major role in [the city's] strategy to increase jobs and its commercial tax base. (Corridor plans attract 40o," The Peace Arch News, Mar.16/02, p. 1) 
As for those concerned about the effects of rapid growth on quality of life, the mayor said city hall remains committed to preserving open space and parkland. But people want to live in [the city], and we're going to let that happen. ("Census shows [the city] BC's fastest-growing," The Peace Arch News, Mar. 16/02, p. 6.)

One of the advantages of a contextual approach is that critical elements of the rhetorical situation can be brought to bear on the features and effects of the texts produced in response to a situation. For example, here the comments of participants reveal that the discourse of environmentalism is vital and dynamic; it is alive with their resolve and commitment to carry on, in the long term, with the agenda set out in the plan-despite significant and strong obstacles. Their comments indicate that there is a contested space where dialogue is potential and an eventuality. This dimension of discourse - outside the written plan-is the ground for those power relations that will ultimately come into play as natural areas policies and conflicts emerge in the future. This tension is reduced in the written plan, however, to a thin ambivalence that effectually closes off the space for such dialogue. Instead, the echoes of contradictory discourses in the plan offer a double-voicedness that enables other interests.

\section{The Pragmatic Effects of The Natural Areas Management Plan}

As the "murmuring" aura that cloaks altruistic statements in the context of global discourse is lifted and inserted into the more local discourses of professional and municipal documents, an alteration of the terms of these discourses makes their prior freight relatively innocuous in their new environment. But the cache of their presence seems to work in the interests of management. Their former persuasive power in favour of environmental protection and community development is now diminished; for the city, however, the new power is productive and internally persuasive. The recontextualized statement offers the conditions of possibility for new discursive formations: new objects, concepts, enunciative positions, and strategies (Foucault P. 3170 ), and these new formations tend to serve the interests of the dominant discourse (here managerial), partly because of the ways in which such discourse closes off other opportunities for uptake, and partly because of its dominance in terms of power.

A restructuring of the Parks department in 2000 saw the creation of two new management units-Urban Forestry and Environmental Services, and Community Development-each with a significant increase in funding and hirings. Urban Forestry and Environmental Services replaced and included the section previously dedicated to merely tree management. Its budget was increased to $\$ 2$ million operations, $\$ 500,000$ capital, and it now has a manager, two coordinators, five technicians. Com- 
munity Development, received $\$ 5000$ for staff training in 2001, and now has two fulltime coordinator positions and one assistant. As the community development coordinator explained, "community development" is now also written into all Parks jobs descriptions: "Although its home is in ... Parks, Recreation ..., the service itself extends across the department and across the city.... [it is] "a defined area representing (not owning) CD (community development) to offer consistency, resource-sharing, clarity and advocacy for it."

As each of these two new management structures has emerged, an important enabling process has been the opportunitites for recontextualizations resulting from changes in the ecology of their two corresponding professions, urban forestry and community development. Sarangi (1998) reports a similar conclusion from studies in management settings: "Professional groups, over a period of time, may appropriate other discursive domains and extend their territoriality" (p.303). She points to these events as "boundaries and critical moments in discourse which may bring to the fore the functional dimension of recontextualization practices" (p. 314).

\section{Conclusion}

To sum up, the results of this study strongly suggest that managerial discourse tends to incorporate and recontextualize less dominant, altruistic discourses with the effect that it reduces the intended pragmatic force of a statement in its prior context. This neutralization may be productive for management and others who share the management idiom, but can change and even subvert the motivations implicit in the prior discourses. This subversion of non-dominant discourses enables the objectivist and exclusionary effects of the managerial style. Ultimately, a certain tension or ambivalence seems to be an overall effect of these competing discourses-what Killingsworth and Palmer characterize as the competing goals of liberal technological societies where "preference for communicative action" is "corrupted by [their] desire for efficiency" (p. 167). Foucault's proposal that there can exist "contradictory discourses within the same strategy" supports such an analysis:

Discourses are tactical elements or blocks operating in the field of force relations; there can exist different and even contradictory discourses within the same strategy. (1981, pp. 101-102)

Although Giddens (1984) and others assert a duality of structure, whereby individuals may strategize around the give and play of structures of institutional power, it seems very difficult to actually alter or dislodge them. In the case of the NAMP, the manager of Parks and Recreation has acknowledged, on the one hand, that community development has not been satisfactorily addressed; on the other hand, he implies 
that community participation in decision-making is a limited enterprise, for "Parks and Recreation must still be [the] 'keepers."' Returning to Mumby's observation, it would seem to be the case that "in organizations the managerial interest most frequently characterizes the framing of organizational reality" (p. 93). This co-optation of altruistic discourse is not dissimilar to the co-optation that Martin (2002) analyzes in his study of the "greening" of geography textbooks. He exposes a process of depoliticalization whereby "green geography is simply canonical geography supplemented by the right kinds of attitude ... a co-option of ecology in place of genuine renovations" (p. 265).

When another's discourse is appropriated, Bakhtin theorizes, "it performs ... as [both] authoritative discourse, and an intemally persuasive discourse" (p. 342). In the case of managerial discourse, authoritative statements from environmentalist and community development discourse become conjoined with the authoritative statements of a dominant managerial discourse, which, for managers, is already "internally persuasive." The appropriated statements can become "indissolubly fused with [ the dominant discourse's] authority" (p. 343-44), for it is "linked to ... power" which is "outside" the statement (Deleuze, p. 79). Together, the statement and power form a strata of power/knowledge wherein power has primacy: the status of the statement "is established by the non-discursive constraints that exist between statements and institutions" (Fairclough 1992, p. 49). This is the problem that Foucault scrutinized but could not elucidate: too often "the transversal relations of resistance [or difference] continue to be restratified, and to encounter or even construct [or reproduce] knots of power" (Deleuze, p. 94) - as a result, negotiation and consensus-building become absorbed into the larger projects of power.

In institutional settings and among those who study organizations, it is generally suggested that researchers repeat such analyses of orders of discourses for the insights they can provide. For example, in Writing Workplace Cultures (2000), Henry identifies the need to provide "analytical tools" for students who will become "discourse workers in organizations":

As discourse workers in organizations, writers are sure to encounter a discourse of management allied with other discourses and enacted in particular forms locally, along with the counterdiscourses these discourses will engender; writers will need analytical tools and training to apprehend the workings of these discourses so as to interpret their implications for themselves as culture members and for organizational authorship. (p. 102) 
Such analysis does provide important interpretive tools, but does not necessarily function as a means to dismantle power relations by itself. As Wodak (1996) reminds us, "the instruments" of discourse analysis "may, but do not have to, lead to emancipation" (p. 32). Chouliaraki and Fairclough (1999) similarly point to the limits of discourse analysis: they argue "that people stand in more or less open relationships to discourse, and relationships which are open in different ways, depending on their social positioning" (p. 2) (itals. mine).

Although Foucault has been criticized for what has been interpreted as an overly pessimistic view of the intransigence of power, these assertions from contemporary theorists don't sound much more optimistic. I would like to end, however, by suggesting that we listen fully to Foucault, who also counseled tactics of resistance, and claimed the "intransitivity of freedom" (1982, p. 223), suggesting that "as a chemical catalyst," resistance can "bring to light power relations" (p. 211). The written natural areas plan, for example, is susceptible to institutional power, but it does not exist in a decontextualized vacuum. Analysis could be used more to bring to the fore those subjects whose interests are otherwise being reconstructed in the mixing of discourses. Analysis can and should expand its repertoire of tools in an effort to more incisively theorize the contextual dimension of a discourse, to co-analyze what is both outside and inside the written text-to reveal the dynamics of written intentions in relation to those other articulated intentions, regrets, and commitments that exist in the nonofficial speech of socially situated subjects.

\section{ENDNOTES}

'I wish to thank the reviewers for their most careful readings of an earlier version of this paper and for their very helpful suggestions.

${ }^{2}$ This data set corresponds to the categories recommended for studying "real-life writing processes" by Van der Geest (1996) as a standard methodology to facilitate the meaningful replication of case studies ( $P .310-11$ ), and to develop an empirical foundation of propositions about the social dimensions of writing (P. 322). 


\section{REFERENCES}

Agar, M. (1985). Institutional discourse. Text. 5 (3), 147-168.

Armstrong, F. (2002). Managing difference: Inclusion, performance and power. Critical Quarterly. 44 (4), Winter, 51-56.

Bakhtin, M.M. (1981). The dialogic imagination. Ed. M. Holquist. C. Emerson and M. Holquist, Trans. Austin: University of Texas Press.

Beaufort, A. (2000). Learning the trade: A social apprenticeship model for gaining writing expertise. Written Communication. 17 (2), April, 185.

Bordum, A. (2002). From tacitknowing to tacit knowledge-emancipation or ideology? Critical Quarterly. 44 (3), Autumn, 50-54.

Burke, K. (1969). A rhetoric of motives. Berkeley: University of California.

Burke, K. (1966). Language as symbolic action. Berkeley: University of California.

Chouliaraki, L. \& Fairclough, N. (1999). Discourse in late modernity. In Discourse in late modernity. Edinburgh: Edinburgh University Press.

Cicourel, A. (1982). Language and belief in a medical setting. In Contemporary perception of language: Interdisciplinary dimensions. Ed. H. Byrnes. Georgetown: Georgetown University Press.

Darcy, M. (2002). Community management: how management discourse killed participation. Critical Quarterly. 44 (4), Winter, 32-39.

Deleuze, G. (1988). Foucault. S. Hand, Trans. Minneapolis: U of Minnesota Press.

Edelman, M. (1984). The political language of the helping professions. Language and politics. Ed. M. Shapiro. London: Basil Blackwell, 44-61.

Fairclough, N. \& Wodak, R. (1997). Critical discourse analysis. Discourse or social interaction. Discourse studies: A multidisciplinary introduction. Vol. 2. Ed. Teun A. van Dijk. London: Sage Publications.

Fairclough, N. (1992). Michel Foucault and the analysis of discourse. Discourse and social change. Cambridge: Polity Press. 
Foucault, M. (1982). Afterward: The subject and power. In Dreyfus, Hubert L. and Paul Rabinow. Michel Foucault: Beyond structuralism and hermeneutics. Chicago: The University of Chicago Press.

Foucault, M. (1988/1965). Madness and civilization. New York: Vintage Books. Foucault, M. (1980/1978). The history of sexuality volume I. R. Hurley, Trans. New York: Vintage Books.

Foucault, M. (1972). The discourse on language. Appendix to The archaeology of knowledge. A. M. Sheridan Smith, Trans. New York: Pantheon Books.

Foucault, M. (1972). The archaeology of knowledge. A. M. Sheridan Smith, Trans. New York: Pantheon Books.

Giddens, A. (1984). The constitution of society. Berkeley: University of California.

Giltrow, J. (2001). Vagrant voices: Summary, citation, authority. Technostyle. 17 (1), Summer, 87-103.

Hansen, H.K. and Salskov-Iversen, D. (2002). Managerialised patterns of political authority: Partners, peddlers and entrepreneurial people. Critical Quarterly. 44 (3), Autumn, 4-18.

Hinton, D. (2002). Triangulating the circle: The three laws of management speak. Critical Quarterly. 44 (3), Autumn, 55-62.

Iedema, R. \& Wodak, R. (1999). Introduction: Organizational discourses and practices. Discourse \& Society. 10 (1), 5-19.

Iedema, R. (1999). Formalizing organizational meaning. Discourse and Society. 10 (1), 49-65.

Jenkins, T. (2002). Management speak. Critical Quarterly. 44 (4), Winter, 17-20.

Killingsworth, J. \& Palmer, J. (1992). Ecospeak: Rhetoric and environmental politics in America. Carbondale: Southern Illinois University Press.

Kristeva, J. (1980/1969). Word, dialogue, and novel. In L. S. Roudiez (Ed.), Desire in language. New York: Columbia University Press.

Lutz, J. (1989). Writers in organizations and how they learn the image: Theory, research, and implications. In C. B. Matalene (Ed.), Worlds of writing. New York: Random House. 
Lyotard, F. (1983). The differend: Phrases in dispute. G. Van Den Abbeele, Trans. Minneapolis: University of Minnesota.

Martin, J. (2002). From little things big things grow: Ecogenesis in school geography. In R. Coe, L. Lingard \& T. Teslenko (Eds.), The rhetoric and ideology of genre (pp. 243-271). Cresskill, NJ: Hampton Press, Inc.

Mumby, D. (1988). Communication and power in organizations: Discourse, ideology, and dominion. Norwood: Ablex Publishing Corporation.

Nietzsche, F. (1957). The use and abuse of history. A. Collins, Trans. New York: Macmillan Publishing Company.

Sarangi, S. (1998). Rethinking recontextualization in professional discourse studies: An epilogue. Text. 18 (2), 301-318.

Sauer, B. A. (1994). The dynamics of disaster: A three-dimensional view of documentation in a tightly regulated industry. Technical Communication Quarterly.3 (4), Fall, 393-419.

Stotsky, S. (1996). Participatory writing: Literacy for civic purposes. In Duin \& Hansen (Eds.), Nonacademic writing: Social theory and technology (pp. 225256). Mahwah, NJ: Lawrence Erlbaum.

Stygall, G. (1991). Texts in oral context: The 'transmission' of jury instructions in an Indiana trial. In C. Bazerman \& J. Paradis (Eds.), Textual dynamics of the professions. Madison: The University of Wisconsin Press.

Van der Geest. T. (1996). Studying 'real-life' writing processes: A proposal and an example. In M. Sharples and T. Van der Geest (Eds.), The new writing environment: Writers at work in a world of technology (pp. 309-322). London: Springer-Verlag.

Wodak, R. (1996). Introduction: Orders and disorders. Disorders of discourse. London: Longman.

West, C. (1984). Medical misfires: Mishearings, misgivings, and misunderstandings in physician-patient dialogues. Discourse Processes, 7, 107-134.

Winsor, D. A. (1994). Invention and writing in technical work: Representing the object. Written Communication. 11 (2), April, 227-250.

Winsor, D. A. (2000). Ordering work: Blue-collar literacy and the political nature of genre. Written Communication, 17 (2), April, 155-184. 


\section{CORPUS OF DOCUMENTS ANALYZED}

Addison, S. "Corridor plans attract 400." The Peace Arch News. March 16, 2002: 1.

British Columbia. Anmual Report 1999. Ministry of Environment, Lands and Parks, Government of British Columbia, 1999.

British Columbia. An Economic Framework for Sustainability.

The Brundtland Challenge and the Cost of Inaction. Eds. A Davidson and M. Dence. The Royal Society of Canada. Halifax: The Institute for Research on Public Policy, 1988.

Caring for the Earth: A Strategy for Sustainable Living. Gland, Switzerland: IUCN, UNEP, and WWF, 1991.

Coquitlam Leisure and Parks Services. Active Living through Community Development: Building a Community Development Team, July 1995.

Coquitlam Leisure and Parks Services. Let's Do It! Community Development Workshop: June 17, 1998.

Croy, O. and G. Ward. "Managing Recreational Access to Natural Areas." Parks and Recreation Canada. Vol. 56 (6), 2000: 16-17.

"Developing a community forest management strategy." 1999. [US source off web] Dictionary of Natural Resource Management. Eds. Julian and Katherine Dunster. Vancouver: UBC Press, 1996.

An Economic Framework for Sustainability. British Columbia Round Table on the Environment and the Economy, 1993.

Goals for Community Forest Programs. 1999.

The Global Partnership for Environment and Development: A guide to Agenda 21. UNCED. Geneva: 1992.

Harris, R. Arboriculture: Integrated Management of Landscape Trees, Shrubs, and Vines. Prentice Hall, Career and Technology: 1992 and 1999.

Hempel, L.C. Environmental Governance: The Global Challenge. Washington, DC: Island Press. 1996. 
Herchmer, B. Creating Community: A Community Development Handbook for the Recreation Practitioner. Fonthill, Ontario: 1996.

International Centre for Sustainable Cities. Publication \#1. 2001.

Johnson, J. and M. Worrall. Chapters 3 and 4: Urban Forestry and the Community." Britain.

Kretzmann, J. and J. McKnight. "Introduction." Building Communities from the Inside Out: A path Toward Finding and Mobilizing a Community's Assets. Evanston, Il: Institute for Policy Research, 1993.

The Global Partnership for Environment and Development: A guide to Agenda 21. UNCED. Geneva: 1992.

Lipkis, A. "Using the Best to Make it Better: Aplying the Best Practices of Urban and Community Forestry to Make Cities Livable and Sustainable." The TREES Project, TreePeople, Los Angeles. Paper presented at North American Forestry Commission of the United Nations Conference in New Brunswick, June 2000.

Living with the Land: Communities Restoring the Earth. Eds. C. Mayer and F. Moosang. Philadelphia and Gabriola Island: New Society Publishers, 1992.

Marsh, D. "Census shows [the city] BC's fastest-growing." The Peace Arch News. March 16, 2002: 6.

McPherson, E.G. "Urban Forestry Issues in North America and Their Global Linkages." Paper presented at North American Forestry Commission of the United Nations Conference in New Brunswick, June 2000.

Natural Areas Management Plan. Calgary Parks and Recreation, 1994.

"New OCP big on business, industry." [City] Now. Dec. 1, 2001: 17.

Park Development and Operation. City of Calgary, 2000.

Our Common Future: World Commission on Environment and Development. [The Brundtland Report] Oxford: Oxford University Press, 1987.

Parks, Recreation and Culture Department. Strategic Organizational Review Team (SORT): Community Development Task Force Report, 1994.

Parks, Recreation and Culture Department. Proposal: Community Development Model. (Submitted to the 1995-96 Fraser Institute/Financial Post Economy in Government Competition), December 15, 1995. 
Parks and Recreation Commission Reports [on Urban Forest Management Strategy Task Force]. Manager of Parks: Oct. 1/95 and Feb. $7 / 96$.

Parks, Recreation and Culture Department. Parks and Recreation Master Plan. City of , 1996.

Parks, Recreation and Culture Departments. Urban Forest Management Task Force. City of 1996.

Parks, Recreation and Culture Department. 1996-2000 Marketing Plan: New Directions in Leisure Excellence. City of , 1996.

Parks, Recreation and Culture Department. 1998 Update: A Report Card on the Master Plan. City of , 1998.

Parks, Recreation and Culture Department. Environmental Overview and Assessment of Proposed Road Improvements at Urban Forest, , $B C, 1998$.

Parks, Recreation and Culture. "Restructuring of the Parks Division." (Inter-Office Memo): June 15, 2000.

Parks, Recreation and Culture Department. Parks, Recreation and Culture Department Strategic Plan. City of 2000.

Parks, Recreation and Culture Department. Strategic Plamning-200I Parks Division, September 28, 2000.

Parks, Recreation and Culture Department. Natural Areas Management Plan. City of , 2001.

Parks, Recreation and Culture Department. Community Development and Partners in Parks Programs: Summary Report, Fall 2001.

Parks, Recreation and Culture Department. Directional Document for Community Development, October 2001.

Planning and Development Department. Official Community Plan. City of , 1996.

Searle, M. "Empowering the Citizen: Advocacy for Recreation and Parks." Recreation Canada. May 1990:

Society of American Foresters. Urban and Community Forestry Position Statement. December 8, 1997. 
Treemendous. How can your community restore the urban forest? Seattle: 1999.

Urban Forestry Master Plan: Mission Statement and Goals. Vancouver: 1996/97.

U.S. Department of Agriculture, Forest Service. Urban and Community Forestry on Course into the Future: Vital Communities Through Healthy Ecosystems-A Strategic Direction. October 1995.

Valencia, R.L. "Management of Green Areas in Mexico City." Paper presented at North American Forestry Commission of the United Nations Conference in New Brunswick, June 2000.

Ward, J. "Community Development and Municipal Recreation." Recreation Canada. December 1986: 6-14. 


\section{APPENDICES}

\section{Appendix 1.Table of Contents of the Natural Areas Management} Plan, 2001

Executive Summary

Park Natural Areas Defined

The Need for a Plan

Development of the Plan

Structure and Content of the Plan

Cornerstone Principles

Sustainability

Access

Communication Among Stakeholders

General Management Themes

Strategic Thrusts

Introduction to the Plan

The Global Context

The [city] Mandate

[city] Context

Cornerstone Principles

1. Sustainability

2. Access

3. Communication Among Stakeholders

Natural Areas Management Themes

Preservation and Protection

Accessibility

Collaboration and Community Participation

Education

Health, Safety and Liability

Aesthetics

Preservation of Property Values and Economic Development

Conflict Management

Cost-Effectiveness

Biodiversity Conservation

Strategic Thrusts

Vegetation Management Strategy

Fauna Management Strategy

Access and Recreation Management Strategy

Tree Hazard Management Strategy

Fire Management Strategy

Coarse Woody Debris Management Strategy

Yard Waste and Refuse Management Strategy

Implementation of the Plan: Appendices ( 7 comprehensive modules) 


\begin{tabular}{|c|c|c|c|}
\hline \multicolumn{4}{|c|}{ Appendix 2. Participants' Conceptions of Priorities and Values } \\
\hline Role & Work Areas & Values & $\begin{array}{l}\text { Key Expressions } \\
\text { from Commentary }\end{array}$ \\
\hline \multicolumn{4}{|l|}{ Managers (6) } \\
\hline $\begin{array}{l}\text { Manager of } \\
\text { Parks }\end{array}$ & $\begin{array}{l}\text { Public Relations, } \\
\text { Planning and Op- } \\
\text { erations, Staff, } \\
\text { Budget, } \\
\text { Commission/Council }\end{array}$ & $\begin{array}{l}\text { city's image } \\
\text { environment } \\
\text { natural areas } \\
\text { community develop- } \\
\text { ment, access and } \\
\text { Recreation }\end{array}$ & $\begin{array}{l}\text { natural areas will be managed } \\
\text { in perpetuity for their } \\
\text { intrinsic values, city of } \\
\text { parks, defending city } \\
\text { actions, directing capital, } \\
\text { political sensitivities }\end{array}$ \\
\hline $\begin{array}{l}\text { Manager of } \\
\text { Urban } \\
\text { Forests }\end{array}$ & $\begin{array}{l}\text { Management } \\
\text { Commission } \\
\text { Staff } \\
\text { Budget } \\
\text { Community relations } \\
\text { Team projects } \\
\text { Report writing }\end{array}$ & $\begin{array}{l}\text { environment } \\
\text { natural areas } \\
\text { community develop- } \\
\text { ment, access and } \\
\text { recreation } \\
\text { managerial control } \\
\text { civic responsibility }\end{array}$ & $\begin{array}{l}\text { environmental sustainability, } \\
\text { an innate sense of team, } \\
\text { parks and recreation must } \\
\text { still be the keepers, a civic } \\
\text { leader, [land] provision } \\
\text { standards, native species }\end{array}$ \\
\hline $\begin{array}{l}\text { Operations } \\
\text { Managers (3) } \\
\text { and Park } \\
\text { Development } \\
\text { Manager }\end{array}$ & $\begin{array}{l}\text { Management } \\
\text { Materials } \\
\text { Staff } \\
\text { Facilities } \\
\text { Budget } \\
\text { Signage } \\
\text { Site development }\end{array}$ & $\begin{array}{l}\text { landscaping } \\
\text { buildings } \\
\text { community } \\
\text { natural areas } \\
\text { education }\end{array}$ & $\begin{array}{l}\text { long-term health of } \\
\text { natural areas, fish } \\
\text { spawning areas, human } \\
\text { access to natural areas, } \\
\text { in the real field, nature's } \\
\text { place in the city, citizens }\end{array}$ \\
\hline $\begin{array}{l}\text { Manager of } \\
\text { Planning, } \\
\text { Research, } \\
\text { and Design }\end{array}$ & $\begin{array}{l}\text { Design of buildings } \\
\text { and playing fields } \\
\text { Habitat protection } \\
\text { Public hearings }\end{array}$ & $\begin{array}{l}\text { environment } \\
\text { wildlife } \\
\text { community } \\
\text { public education }\end{array}$ & $\begin{array}{l}\text { protect the natural } \\
\text { environment, parks } \\
\text { standards }\end{array}$ \\
\hline \multicolumn{4}{|c|}{ Commissioners (2) } \\
\hline $\begin{array}{l}\text { Commis- } \\
\text { sioners (2) }\end{array}$ & $\begin{array}{l}\text { Community liaison } \\
\text { Public relations } \\
\text { Council } \\
\text { Advocacy }\end{array}$ & $\begin{array}{l}\text { community develop- } \\
\text { ment, communica- } \\
\text { tion }\end{array}$ & $\begin{array}{l}\text { natural areas } \\
\text { volunteerism }\end{array}$ \\
\hline
\end{tabular}




\begin{tabular}{|c|c|c|c|}
\hline Role & Work Areas & Values & $\begin{array}{l}\text { Key Expressions } \\
\text { from Commentary }\end{array}$ \\
\hline \multicolumn{4}{|l|}{ Senior Staff (2) } \\
\hline $\begin{array}{l}\text { Urban } \\
\text { Forest } \\
\text { Technician }\end{array}$ & $\begin{array}{l}\text { Implementation in } \\
\text { the field: in parks } \\
\text { Tree Hazards } \\
\text { Trails } \\
\text { Protection activities } \\
\text { Public education and } \\
\text { Liaison } \\
\text { Report writing }\end{array}$ & $\begin{array}{l}\text { environment } \\
\text { habitat } \\
\text { community develop- } \\
\text { ment, access and } \\
\text { recreation, natural } \\
\text { areas }\end{array}$ & $\begin{array}{l}\text { timing work to nature's } \\
\text { cycle, preservation of } \\
\text { natural or indigenous } \\
\text { areas, ellvironmental } \\
\text { protection, higher-level } \\
\text { planning, external } \\
\text { input }\end{array}$ \\
\hline $\begin{array}{l}\text { Environment } \\
\text { Education } \\
\text { Coordinator }\end{array}$ & $\begin{array}{l}\text { Public education } \\
\text { Habitat protection } \\
\text { Report writing }\end{array}$ & $\begin{array}{l}\text { community } \\
\text { development } \\
\text { environment }\end{array}$ & $\begin{array}{l}\text { community participa- } \\
\text { tion, community } \\
\text { development, getting } \\
\text { our house in order, } \\
\text { natural areas }\end{array}$ \\
\hline \multicolumn{4}{|c|}{ External Participants (5) } \\
\hline $\begin{array}{l}\text { Advisory } \\
\text { Committee } \\
\text { Members (3) }\end{array}$ & $\begin{array}{l}\text { Community input } \\
\text { Protection of urban } \\
\text { forests } \\
\text { Advocacy }\end{array}$ & $\begin{array}{l}\text { democratic participa- } \\
\text { tion, environmental } \\
\text { sustainability, } \\
\text { activism } \\
\text { natural areas } \\
\text { volunteerism } \\
\text { public education }\end{array}$ & $\begin{array}{l}\text { - forest preservation, } \\
\text { urban ecology, controlled } \\
\text { access, think locally, } \\
\text { their intrinsic values, } \\
\text { decades and centuries, } \\
\text { national monuments } \\
\text { [parks] }\end{array}$ \\
\hline $\begin{array}{l}\text { Registered } \\
\text { Professional } \\
\text { Forester }\end{array}$ & $\begin{array}{l}\text { Fire Protection } \\
\text { Mutual Aid }\end{array}$ & $\begin{array}{l}\text { natural environment } \\
\text { public education }\end{array}$ & $\begin{array}{l}\text { fire ecology, eco- } \\
\text { systems of the parks, } \\
\text { fire is a natural process, } \\
\text { forest health, fire's } \\
\text { natural role }\end{array}$ \\
\hline $\begin{array}{l}\text { Fire Chief } \\
\text { of City }\end{array}$ & $\begin{array}{l}\text { Fire Protection } \\
\text { Mutual Aid } \\
\text { Operations }\end{array}$ & $\begin{array}{l}\text { jurisdictional power } \\
\text { chain of command }\end{array}$ & $\begin{array}{l}\text { fire-fighting in our } \\
\text { forested parks }\end{array}$ \\
\hline
\end{tabular}

